\title{
Intraoperative Neurophysiology Practice in the Surgical Treatment of Posterior Fossa Lesions: Cerrahpașa Experience
}

\author{
Posterior Fossa Lezyonlarının Cerrahi Tedavisinde Intraoperatif Nörofizyoloji \\ Uygulamaları: Cerrahpașa Deneyimi
}

(D) Emine Taşkıran1, (D) Barış Küçükyürük²

1ijstanbul University-Cerrahpașa, Cerrahpașa Faculty of Medicine, Department of Neurology, İstanbul, Turkey

2istanbul University-Cerrahpașa, Cerrahpașa Faculty of Medicine, Department of Neurosurgery, İstanbul, Turkey

\begin{abstract}
Introduction: Posterior fossa surgery involves a risk of injury on a variety of critical neurological structures. Intraoperative neuromonitoring (IONM) has become a routine scrutiny with newly developed tests for sparing these structures. This present study aims to evaluate the IONM experience in posterior fossa surgery of a tertiery neurosurgical centre.

Methods: Forty-five patients (26 females, 19 males; age between 2 and 72 years) who underwent surgery for different posterior fossa pathologies from 2016 to 2019 were retrospectively evaluated.

Results: Six and thirteen patients experienced extremity motor evoked potential (MEP) and somatosensory evoked potential changes respectively. Brainstem auditory evoked potential changes were seen in four patients. Corticobulber MEP (COMEP) of facial nerve deteriorated in seven patients. All new onset neurological deficits of cranial nerves or long tracts were concordant with IONM findings except for one patient who developed $6^{\text {th }}$ nerve palsy without COMEP findings. Loss of neurological function immediately after surgery was observed in 13 patients while permanent evident neurological worsening occurred in five patients.
\end{abstract}

Conclusion: IONM is an indispensable component of the skull base surgery. Comprehensive multimodality monitoring provides a real-time, complete assessment of critical neurological structures, facilitates safer and more aggressive management and thus improves quality of life.

Keywords: Blink reflex, brainstem auditory evoked potential, corticobulber motor evoked potential, multimodality, neuromonitoring, posterior fossa lesions, skull base surgery

\section{öz}

Amaç: Posterior fossa lezyonlarının cerrahi tedavisi, çeșitli kritik nörolojik yapılarda yaralanma riski içerir. Intraoperatif nöromonitörizasyon (IONM), yeni geliștirilen yöntemler sayesinde bu yapıları korumak için rutin bir inceleme haline gelmiştir. Bu çalışma, üçüncü basamak bir nöroșirürji merkezinin posterior fossa cerrahisinde IONM deneyimini değerlendirmeyi amaçlamaktadır.

Yöntemler: 2016-2019 yılları arasında farklı posterior fossa patolojileri için ameliyat edilen 45 hasta (26 kadın, 19 erkek; 2 ila 72 yıl) retrospektif olarak incelendi.

Bulgular: Sırasıyla altı ve 13 hastada, ekstremite motor uyarılmış potansiyeli (MEP) ve somatosensoriyel uyarılmış potansiyel değişiklikleri meydana geldi. Dört hastada beyin sapı ișitsel uyarılmıș potansiyel değișiklikleri görüldü. Fasiyal sinirin kortikobulber MEP (CoMEP) 7 hastada kötülești. Kraniyal sinirlerin veya uzun traktların tüm yeni başlayan nörolojik defisitleri, CoMEP bulguları olmaksızın 6. sinir felci gelișen bir hasta dıșında, IONM bulguları ile uyumlu idi. Ameliyattan hemen sonra nörolojik fonksiyon kaybı 13 hastada gözlenirken, bunlardan beşinde belirgin düzeyde kalıcı nörolojik kötüleșme meydana geldi.

Sonuç: IONM kafa tabanı cerrahisinin vazgeçilmez bir bileşenidir. Kapsamlı çok modlu IONM, kritik nörolojik yapıların gerçek zamanlı, eksiksiz bir değerlendirmesini sağlar ve daha güvenli ve daha agresif bir tedavi yönetimini mümkün kılarak yaşam kalitesini yükseltir.

Anahtar Kelimeler: Göz kırpma refleksi, beyin sapı ișitsel uyarılmış potansiyel, kortikobulber motor uyarılmış potansiyel, çok modlu, nöromonitorizasyon, posterior fossa lezyonları, kafa tabanı ameliyatı
Address for Correspondence/Yazışma Adresi: Barıș Küçükyürük, İstanbul University-Cerrahpaşa, Cerrahpaşa Faculty of

Medicine, Department of Neurosurgery, i̇stanbul, Turkey

Phone: +90 5337496232 E-mail: baris.kucukyuruk@istanbul.edu.tr ORCID ID: orcid.org/0000-0002-0077-110X

Cite this article as/Atıf: Taşkıran E, Küçükyürük B. Intraoperative Neurophysiology Practice in the Surgical Treatment of Posterior Fossa Lesions: Cerrahpaşa Experience. İstanbul Med J 2020; 21(5): 344-9.
Received/Geliș Tarihi: 29.01.2020 Accepted/Kabul Tarihi: 18.06 .2020

(C) Copyright 2020 by the University of Health Sciences Turkey, Istanbul Training and Research Hospital/istanbul Medical Journal published by Galenos Publishing House.

(C) Telif Hakkı 2020 Sağıı Bilimleri Üniversitesi Istanbul Ĕgitim ve Araştırma Hastanesi/Istanbul Tıp Dergisi, Galenos Yayınevi tarafından basılmıștır. 


\section{Introduction}

Cranial base surgery aims to provide an optimal treatment for pathology with minimal or no neurological deficit in order to protect the quality of life. Intraoperative neurophysiologic monitoring (IONM) has become an imperative component of skull base surgery to avoid unobtrusive maneuvers that can result in the injury of delicate nuclei, tracts, or nerves and thus a hazardous neurologic injury $(1,2)$.

The posterior cranial fossa is the largest of the 3 cranial fossae and contains a complex anatomy of vascular and neuronal structures, which include 10 of 12 pairs of cranial nerves (CN), long tracts of motor activities and sensory pathways and centres for controlling balance and regulating consciousness (3). Therefore, IONM for posterior fossa surgery consists of long tracts monitoring, several CN mapping and monitoring and also brainstem reflex tests, which has been developed recently to evaluate the integrity of brainstem structures (4-7). However, there is no single test that incorporates all of them. Therefore, IONM of skull base surgery is a multimodality concept that necessitates the use of a number of modalities complementing each other simultaneously in order to evaluate the integrity of neurologic structures.

This article reports the clinical and physiological outcomes achieved in posterior fossa surgeries accompanied by IONM in a tertiary referral hospital.

\section{Methods}

\section{Ethical Approval}

The study was conducted with the approval of İstanbul UniversityCerrahpaşa, Cerrahpaşa Faculty of Medicine Ethical Committee (reference no: 2020/70721) in concordance with the Declaration of Helsinki. Written informed consent was obtained from all the patients.

\section{Patient Population}

Forty-five patients (26 females, 19 males; mean 41.2 years; 2-72 years) who underwent surgery for a variety of posterior fossa pathologies accompanied with IONM from March 2016 to May 2019 were retrospectively evaluated. Demographic information, surgical resection rates, pathology, IONM modalities, techniques, electrophysiological findings and neurologic examination were evaluated.

All the patients reported in this series were informed preoperatively about the IOMN application, since the IOMN procedure is already a well described and approved technique. Due to the retrospective nature of this study, patient consent was not sought.

\section{Intraoperative Neuromonitoring}

Mapping and monitoring techniques were utilised for intraoperative neurophysiology. Mapping identified CNs and their nuclei, and monitoring continuously assessed the functional integrity of the pathways and reflex circuits. All the recordings, stimulation and data processing were performed using Cadwell elite IONM system by a clinical neurophysiologist (E.T.) certified for intraoperative neuromonitoring by the International Society of Intraoperative Neurophysiology.

Standardised institutional setup was used. Recording muscles were determined according to the lesion's location and surgical approach. The stainless steel needle electrodes (13-19 mm, Xi'an friendship medical company) were used to record the muscle responses for motor evoked potentials (MEPs) and electromyography (EMG) as well as to stimulate the peripheral nerves for somatosensory evoked potential (SEP). Disposable corkscrew electrodes were used for the stimulation of MEPs and also for the recording of cortical SEPS. SEPs were obtained by stimulating the median or ulnar nerves and recording cortically with an electrode montage of C3'-Fz/C4'-Fz or C3'-C4'/ C4'- C3', while the lower extremities' SEPs were obtained by stimulating the posterior tibial nerves recording from cortical CZ'-FZ and C3'-CZ'/C4-CZ'. These SEPs monitored the sensory pathway. SEP recordings were set up with a sensitivity of $0.5-1 \mu \mathrm{V} / \mathrm{mm}$ and a sweep speed of $100 \mathrm{msec}$; filter settings were set to $30-700 \mathrm{~Hz}$; the stimulus frequency was $1.7-4.71 \mathrm{~Hz}$ and the stimulation duration was 200-300 $\mu$ s for the median/ulnar nerve and 300-500 $\mu$ s for the tibial nerve. The mean stimulus intensity was 15-20 and 30-40 mA for median/ulnar and tibial nerves, respectively.

The corticospinal motor system was evaluated with extremity MEPs, which were obtained by stimulating the motor cortex transcranially (C1) $\mathrm{C} 2$ for right MEP, C2/C1 for left) and recording from the lower and upper extremities (if we could not get responses from this montage, we used the C3/C4). Corticobulber motor evoked potential (CoMEP) for muscles innervated by the CNs was obtained using C3-Cz or C4-Cz montages (according to the international 10-20 system for electroencephalogram) by activating the corticobulber tract. MEP responses were recorded from the appropriate muscles contralateral to the lesion location. Multipulse stimulation consisting of 5-6 pulses of $0.5 \mathrm{~ms}$ duration with an interstimulus interval (ISI) of 3-4 ms was used for MEPs. Stimulation intensities varied between 100-600 V according to the individual. For recording CoMEPs, we used a short train consisting of 4 or 5 stimuli each with durations of $0.5 \mathrm{~ms}$, seperated by an ISI of 1.5 and an intensity typically from 50-250 V. Simultaneously, we opened a different window for excluding peripheral responses in CoMEP. We applied a single stimulus to the same electrodes at $90 \mathrm{~ms}$ after delivering a short train of stimuli in order to exclude distal CN excitation by the absence of single pulse responses as described by Dong et al. (8).

CN mapping was achieved using a monopolar or bipolar handheld stimulating electrode to find regions of the tumour that are not associated with the nervous system and identify $\mathrm{CN}$ trajectories. Mapping of CN motor nuclei, in case of necessity, was used for the surgical planning and the safe surgery to the brainstem. CN monitoring was provided with EMG and CoMEP.

Brainstem auditory evoked potential (BAEP) reflecting neuronal activity in the auditory nerve, cochlear nucleus, superior olive and inferior colliculus of the brainstem was obtained by stimulating with click stimuli from disposible foam ear tips and recording from A1/A2 electrodes placed ear lobe and cortical electrode CZ.

Blink reflex (BR), which is one of the brainstem reflexes, was performed bilaterally as a monitoring tool for brainstem reflexes, evaluating trigeminal afferents, brainstem connections between the trigeminal and facial nuclei and the facial nerve. We applied 1 to 5 rectangular constant-current stimuli with an ISI of $2 \mathrm{~ms}$, an intensity of 20-60 mA and a train repetition rate of $0.4 \mathrm{~Hz}$ over the supraorbital nerve as described by Deletis et al. (9). 
Monitoring was started immediately after anaesthesia induction and continued until the termination of the surgical procedure, as recommended by the American Clinical Neurophysiology Society in 2009 (10). All surgical procedures were followed on the visual screen in the operating room during surgery.

\section{Anaesthesia}

Total intravenous anaesthesia consisting of propofol $(1.5-2 \mathrm{mg} / \mathrm{kg}$ for anaesthesia induction and $6-10 \mathrm{mg} / \mathrm{kg} / \mathrm{h}$ for maintenance) plus remifentanil $(0.15 \mu \mathrm{g} / \mathrm{kg} / \mathrm{min})$ was used in all the patients. A short halflife muscle relaxant (rocuronium, $0.5 \mathrm{mg} / \mathrm{kg}$ ) was used only during the time of tracheal intubation. We avoided the use of volatile anaesthetics since they reduce the MEP amplitude significantly compared to propofol $(11,12)$. A bite block was placed to prevent tongue injuries during the intraoperative MEP monitoring.

\section{Warning Criteria for Intraoperative Neurophysiologic Changes}

Reproducible cortical peak-to-peak amplitude decrements of more than $50 \%$ or $10 \%$ increases in the latency of the primary SEP cortical response (N20, P37) was considered a significant surgical event that is a cause for concern and heightened vigilance and/or should be intervened. These parameters have been summarised in a position statement by the American Society of Neurophysiological Monitoring (2).

The surgeon was informed as soon as any neurophysiologic change occurred, even if the warning criteria has not been fulfilled. However, a true warning event was decided only if changes were reproducible and continued to worsen in the following recordings.

Disappearance or consistent $>50 \%$ MEP amplitude reduction when warranted by sufficient response stability, or amplitude reduction clearly exceeding variability when responses are less stable were considered significant warning signs. We did not use threshold criteria for MEPs and CoMEPs because of the lack of empirical evidence for constant voltage stimulation that was not documented.

Free-running EMG recording spontaneous muscle activity was observed for detecting surgically driven mechanical irritation and the possibility of damage of the CNs. In case spontanous activity was observed, surgery was interrupted and CoMEP was immediately repeated, along with continuous CoMEP measurements during the critical resection.

An amplitude decrement of more than $50 \%$ and an increase in latency of waves III and IV/V for more than $0.5 \mathrm{msec}$ were considered critical in BAEP monitoring (13).

Disappearance was considered a significant warning criteria for BR during the surgery.

\section{Statistical Analysis}

Data given in this study was analysed with IBM SPSS v23.0 (Chicago, USA). Only descriptive statistics were performed as this article does not include any inferential statistical data.

\section{Results}

Demographic information of the patients, location of the pathology, surgical resection rates, persistant IONM changes and histopathological results are summarised in Table 1. IONM recordings of 45 patients were evaluated. $\mathrm{CN}$ mapping and monitoring of $3-12^{\text {th }} \mathrm{CNs}$ according to the tumour location, BAEP for $8^{\text {th }} \mathrm{CN}$ and brainstem monitoring, SEP for posterior cord and lemniscal system, MEPs for corticospinal and corticobulbar tractus monitoring were performed in all the patients.

Table 1. Demografic data, extent of resection, location, hystopathological findings, preoperative and postoperative neurological examination and IONM findings of patients

\begin{tabular}{|c|c|c|c|c|c|c|c|}
\hline Pt No & Age, gender & Pathology & Location & Excition & $\begin{array}{l}\text { Preop } \\
\text { examination }\end{array}$ & $\begin{array}{l}\text { Early postop } \\
\text { examination }\end{array}$ & Persistant ionm change \\
\hline \multicolumn{8}{|c|}{ New deficit group } \\
\hline 1 & $55, M$ & Ependymoma & Medulla & Grosstotal & Hemiparesis & Hemiplegia & MEP amplitude decrease \\
\hline 2 & $23, \mathrm{~F}$ & Epidermoid & CPA & Grosstotal & HB1 & HB2 & BR threshold increase \\
\hline 3 & $49, \mathrm{M}$ & Epidermoid & CPA & Grosstotal & HB2 & HB3 & $\begin{array}{l}\text { COMEP amplitude decrease } \\
75 \%\end{array}$ \\
\hline 4 & $22, \mathrm{~F}$ & Epidermoid & $\mathrm{CPA}$ & Grosstotal & HB1 & HB2 & BR threshold increase \\
\hline 5 & $21, \mathrm{~F}$ & Glioneuronal tumour & $4^{\text {th }}$ ventricle & Grosstotal & BSF & Nystagmus & None \\
\hline 6 & $42, M$ & Meningioma & Petroklival & Subtotal & BSF, HL & HB4 & $\begin{array}{l}\text { COMEP amplitude decrease } \\
70 \%\end{array}$ \\
\hline 7 & $28, M$ & Vestibular schwannoma & CPA & Grosstotal & BSF, HL & HB4 & $\begin{array}{l}\text { COMEP amplitude decrease } \\
65 \%\end{array}$ \\
\hline 8 & $67, M$ & Vestibular schwannoma & $\mathrm{CPA}$ & Subtotal & $\mathrm{HL}$ & HB5 & COMEP loss \\
\hline 9 & $24, \mathrm{~F}$ & Vestibular schwannoma & CPA & Grosstotal & BSF, HL & HB3 & COMEP loss \\
\hline 10 & $63, \mathrm{~F}$ & Vestibular schwannoma & $\mathrm{CPA}$ & Grosstotal & BSF, HL & HB5 & COMEP loss \\
\hline 11 & $22, \mathrm{~F}$ & Vestibular schwannoma & CPA & Subtotal & $\mathrm{HL}$ & HB2 & $\begin{array}{l}\text { COMEP amplitude decrease } \\
64 \%\end{array}$ \\
\hline 12 & $23, \mathrm{~F}$ & Vestibular schwannoma & CPA & Subtotal & BSF, HL & HB2 & $\begin{array}{l}\text { COMEP amplitude decrease } \\
50 \%\end{array}$ \\
\hline 13 & $19, \mathrm{~F}$ & Vestibular schwannoma & CPA & Subtotal & HB1 & HB2 & COMEP morphological change \\
\hline
\end{tabular}


Taşkıran and Küçükyürük. Intraoperative Monitorisation in Posterior Fossa Surgeries

Table 1. contiuned

\begin{tabular}{|c|c|c|c|c|c|c|c|}
\hline \multicolumn{8}{|c|}{ No new deficit group } \\
\hline 14 & $43, M$ & Anaplastik astrositoma & Cerebellum & Subtotal & Normal & No new deficit & BAEP change \\
\hline 15 & $3, \mathrm{~F}$ & Anaplastik astrositoma & Cerebellum & Grosstotal & Vomiting & No new deficit & None \\
\hline 17 & $12, \mathrm{M}$ & Ependymoma & $4^{\text {th }}$ ventricle & Grosstotal & BSF & No new deficit & None \\
\hline 18 & $28, F$ & Ependymoma & $4^{\text {th }}$ ventricle & Subtotal & BSF & No new deficit & None \\
\hline 20 & $55, \mathrm{M}$ & Epidermoid & CPA & Grosstotal & BSF, HL & HB1 & None \\
\hline 21 & $43, \mathrm{~F}$ & Epidermoid & CPA & Grosstotal & Normal & HB1 & $\begin{array}{l}\text { COMEP amplitude decrease } \\
55 \%\end{array}$ \\
\hline 22 & $19, \mathrm{~F}$ & Epidermoid & CPA & Grosstotal & BSF, HL & HB1 & None \\
\hline 26 & $39, \mathrm{~F}$ & Ganglioglioma & Cerebellum & Subtotal & BSF & No new deficit & $\begin{array}{l}\text { MEP and SEP amplitude } \\
\text { decrease }\end{array}$ \\
\hline 27 & $43, \mathrm{M}$ & Hemangioblastoma & Medulla & Grosstotal & Normal & No new deficit & None \\
\hline 28 & $9, M$ & Medulloblastoma & $4^{\text {th }}$ ventricle & Grosstotal & Normal & HB1 & None \\
\hline 29 & $9, \mathrm{~F}$ & Medulloblastoma & $4^{\text {th }}$ ventricle & Grosstotal & BSF & No new deficit & COMEP loSS \\
\hline 30 & $52, \mathrm{~F}$ & Meningioma & CPA & Grosstotal & Normal & HB1 & None \\
\hline 31 & $60, \mathrm{~F}$ & Meningioma & CPA & Grosstotal & Normal & HB1 & None \\
\hline 32 & $38, F$ & Meningioma & Petroklival & Subtotal & Normal & HB1 & None \\
\hline 38 & $25, \mathrm{~F}$ & Pilocytic astrocytoma & Cerebellum & Subtotal & BSF & No new deficit & None \\
\hline 39 & $36, M$ & Vestibular schwannoma & CPA & Subtotal & $\mathrm{HL}$ & HB1 & None \\
\hline 40 & $72, \mathrm{M}$ & Vestibular schwannoma & CPA & Subtotal & BSF, HL & HB1 & SEP loss \\
\hline 41 & $64, \mathrm{M}$ & Vestibular schwannoma & CPA & Subtotal & $\mathrm{HL}$ & HB1 & SEP loss \\
\hline 42 & $28, \mathrm{M}$ & Vestibular schwannoma & CPA & Subtotal & Normal & HB1 & None \\
\hline 43 & $38, F$ & Vestibular schwannoma & CPA & Grosstotal & BSF, HL & HB4 & None \\
\hline 44 & $68, F$ & Vestibular schwannoma & CPA & Subtotal & BSF, HL & HB1 & None \\
\hline 45 & $67, \mathrm{~F}$ & Vestibular schwannoma & CPA & Subtotal & $\mathrm{HL}$ & HB1 & None \\
\hline
\end{tabular}

Tumours in this series were located at the cerebellopontin angle (CPA) in 25 patients, petroclival region in 4 , along petrous bone in 2 , fourth ventricle in 5, cerebellar hemisphere in 4 and brainstem in 5 .

Neurological deficits were present in 31 patients at the time of admission (Table 1). Clinical signs due to brain stem compression were manifested in 23 patients, while hearing loss in 17 patients was the second most common finding in our series. Facial nerve palsy was present in 3 patients during the preoperative period.

Histopathological diagnoses were vestibuler schwannoma in 14 patients, epidermoid in 9, meningioma in 8, ependimoma in 4, pilocytic astrocytoma in 2, anaplastic astrocytoma in 2, medulloblastoma in 2, pleomorphic xanthoastrocytoma in 1, hemangioblastoma in 1 , 
ganglioglioma in 1 and glioneuronal tumour in 1. Microscopic gross total resection and subtotal resections were achieved in 23 and 22 patients, respectively.

Immediate postoperative new neurologic deficit occurred in 13 patients. Preoperatively present hemiparesis of a patient with ependimoma of the medulla oblongata worsened due to hemiplegia. Another patient with a glioneuronal tumour located in the fourth ventricle developed right-sided $6^{\text {th }}$ nerve palsy. The remaining 11 patients showed facial palsy of varying degree.

Neurological deficits of 4 patients, 1 with hemiplegia and 3 with facial palsy, returned to the initial neurological status before discharge, and in 2 other patients: 1 with facial palsy and 1 with $6^{\text {th }}$ CN palsy, returned to normal at the last follow-up. At long term, disfiguring facial palsy (House-Brackmann scale 3 or above) was present in 5 patients and mild palsy (House-Brackmann scale 2) in 2.

Extremity MEP and SEP changes were seen in six and 13 patients, respectively. Of these, 3 patients in MEP and 5 in SEP met the warning criteria. However, only one patient having persistant MEP changes revealed postoperative new extremity deficit.

BAEP changes were present in four patients with lesions located in the $4^{\text {th }}$ ventricle, which showed brainstem compression.

CoMEP of abducens, facial, glossopharyngeal and hypoglossal nerves were routinely applied to all the patients in this series. CoMEP of the $6^{\text {th }}$ nerve did not show warning criteria in any patient. IONM of the $7^{\text {th }}$ nerve revealed CoMEP changes in 17 patients. Six of 17 patients had amplitude decrement less than $50 \%$ or showed morphological changes, and 11 met the warning criteria (9 persistent and 2 transient). Of 9 patients showing persistent CoMEP changes, 7 had neurological worsening after the surgery.

BR was evaluated in 33 patients in this series. BR was lost in six patients and two patients with increased stimulation threshold that all came up with facial nerve deficit postoperatively.

\section{Discussion}

The main objective of obtaining total resection in neurosurgical practice has been significantly changed over to sustaining the quality of life. IONM has been an indispensable tool to achieve this goal by facilitating to achievement of maximal resection while preserving vital structures. Use of IONM in neurosurgical procedures promoted a significant decrease of neurological complications from as high as $37 \%$ to less than $5 \%$ in some recent series $(14,15)$.

Multimodality is essential during challenging surgical procedures since classical IONM methods such as SEP and BAEP allow to evaluate the neurological function in less than $20 \%$ of brainstem areas (16). To have a holistic understanding of $\mathrm{CN}$ and brainstem functioning, $\mathrm{CN}$ assessments such as COMEP and brainstem reflexes such a BRs, and mapping by triggered EMG have been developed and found wide use $(5,8,9,17)$.

This multimodality understanding proved to be useful in our series, since no patients who had a new postoperative neurological deficit showed prominent BAEP or SEP changes in this series. On the other hand, all patients, except one with postoperative $6^{\text {th }}$ nerve palsy, showed some changes in at least one of the modalities during surgery.

In more than two-thirds of cases in this series, the facial nerve was at risk during surgery. More specifically, pathologies were located in CPA or along the petrous bone, which is adjacent to the cisternal segment of the facial nerve in 31 patients. Concordant to this, facial palsy was the most common postoperative new neurological deficit in this patient cohort. Facial nerve can be evaluated during surgery either via stimulation of the nerve where it exits from the brainstem with a hand-held probe (mapping) or with CoMEP $(8,18)$. CoMEP monitors the functional integrity of the corticobulbar tracts arising from the cortex, passing through the cranial motor nuclei and terminating in the muscles innervated by CNs $(8,19)$. Several advantages of CoMEP were described over mapping with a hand-held probe $(8,11)$. First, defining the proximal part of the facial nerve and stimulating it in the presence of a large tumour may require extensive maneuvers that may damage the nerve. Second, CoMEP does not interrupt the course of the surgery, while mapping requires the surgeon to stop the surgical dissection. Third, CoMEP provides evaluation of the facial nerve entirely from its cortical origin to muscle terminations, while direct stimulation only assesses the facial nerve distal to the brainstem.

CoMEP was performed as part of a multimodal IONM setup in all cases in this series. CoMEP abnormalities were present in all the patients (11 patients) with postoperative new facial nerve deficit, while 8 showed the warning criteria, 2 amplitude decreament less than $50 \%$ and threshold increase in BR eliciting and 1 morphological change. Eight patients with warning criteria included all the 5 patients with disfiguring postoperative facial palsy, 2 patients who returned to the initial status and one had mild persistent facial palsy. Along 5 patients with disfiguring facial palsy, BR was lost in 4 of them at the end of the procedure and was not elicited in one patient at the baseline recording.

BR was recommended as a new tool to evaluate structures involved in the reflex arc, including trigeminal afferents, brainstem connections between the trigeminal and facial nuclei and the facial nerve (19). BR was found to have a strong correlation with facial and/or trigeminal CoMEPs during skull base surgery in 21 patients undergoing posterior fossa surgeries, with this being a predictor of clinical outcome (4). Our results also suggest that $B R$ is a complementary tool to facial nerve CoMEPs to specifically determine the severity of facial nerve deficits, as all cases with permanent facial nerve deficits in our series showed BR abnormalities whether the CoMEP changes met the warning criteria or not. We also concluded that severe facial nerve palsy is concordant with CoMEP changes in more than one muscle group together with BR loss. Patients with new mild deficit or patients with improving new deficits showed CoMEP changes in only the muscle group or had preserved BR.

Although extremity MEP and SEP are noted to be not trustworthy in evaluating CNs, these modalities have an important place in the assessment of long tracts consisting of the corticospinal tract in MEP and the dorsal column-medial lemniscal path in SEP. In our practice, 16 patients had intraoperative SEP changes and 6 had MEP changes. However, only one patient had transient hemiparesis as new neurological deficit regarding extremities, which suggests that these modalities are powerful tools to determine the harm done to the long tracts. 
Our policy is to stop the dissection at that surgical plane and allow neurological structures to recover. During this break, we let the IONM team to reevaluate SEP and MEP and interact with neuroanesthesia team to increase the blood pressure and correct other parameters.

These cumulative findings led us to form a policy regarding the surgical technique in posterior fossa surgeries assessed with IONM. According to this, surgical dissection was halted each time when surgeons were warned due to changes in IONM modalities. In the presence of amplitude decreaments of less than $50 \%$ or significant morphological changes, surgical dissection site has been changed to another part of the tumour, whether intracapsular or extracapsular. Further similar decreases or emergence of warning criteria led to the pause of the surgery until ameliorating signs in IONM were obtained. Such repeated periods in vestibuler schwannoma surgery may impose damage to facial nerve and cause deficit spesifically in presence of CoMEP warning signs and BR loss. On the other hand, our experience in epidermoids is a different case. Out of 9 epidermoids in this series, 3 had postoperative new facial palsy of HB 2. Warning criteria was detected in 2 and amplitude decreaments were seen in 1. At this step, we followed BR as a decision maker and continued surgery to achieve gross total resection in all the epidermoids.

However, significant acute decreases in facial CoMEP may hint damage to vascular supply of the facial nerve. In such cases, surgical team washes the surgical site around the nerve with warm saline and topical papaverine has been applied in some cases. Continuing the surgery in such cases during early times in this series always ended with disfiguring facial palsy.

\section{Conclusion}

These findings show that neurophysiologic monitoring is an indispensable component of posterior fossa/skull base surgery. Multimodality monitoring rather than one modality provides a realtime, comprehensive assessment of nervous system function and allows for more aggressive management with safer surgical intervention and improved quality of life.

\section{Ethics}

Ethics Committee Approval: The study was conducted with the approval of İstanbul University-Cerrahpaşa, Cerrahpaşa Faculty of Medicine Ethical Committee (ref no: 2020/70721) in concordance with the Declaration of Helsinki.

Informed Consent: Written informed consent was obtained from all the patients.

Peer-review: Externally peer-reviewed.

Authorship Contributions: Surgical and Medical Practices - E.T., B.K.; Concept - E.T., B.K.; Design - E.T., B.K.; Data Collection or Processing E.T., B.K. ; Analysis or Interpretation - E.T., B.K.; Literature Search - E.T., B.K.; Writing - E.T., B.K.

Conflict of Interest: No conflict of interest was declared by the authors.

Financial Disclosure: The authors declared that this study received no financial support.

\section{References}

1. Macdonald DB. Intraoperative motor evoked potential monitoring: overview and update. J Clin Monit Comput 2006; 20: 347-77.

2. Toleikis JR, American Society of Neurophysiological Monitoring. Intraoperative monitoring using somatosensory evoked potentials. A position statement by the American Society of Neurophysiological Monitoring. J Clin Monit Comput 2005; 19: 241-58.

3. Rhoton AL Jr. Cerebellum and fourth ventricle. Neurosurgery 2000; 47: S7-27.

4. Deletis V, Urriza J, Ulkatan S, Fernandez-Conejero I, Lesser J, Misita D. The feasibility of recording blink reflexes under general anesthesia. Muscle Nerve 2009; 39: 642-6.

5. Neuloh G, Bogucki J, Schramm J. Intraoperative preservation of corticospinal function in the brainstem. J Neurol Neurosurg Psychiatry 2009; 80: 417-22.

6. Romstock J, Strauss C, Fahlbusch R. Continuous electromyography monitoring of motor cranial nerves during cerebellopontine angle surgery. J Neurosurg 2000; 93: 586-93

7. Ulkatan S, Jaramillo AM, Tellez MJ, Goodman RR, Deletis V. Feasibility of eliciting the $\mathrm{H}$ reflex in the masseter muscle in patients under general anesthesia. Clin Neurophysiol 2017; 128: 123-7.

8. Dong CC, Macdonald DB, Akagami R, Westerberg B, Alkhani A, Kanaan I, et al. Intraoperative facial motor evoked potential monitoring with transcranial electrical stimulation during skull base surgery. Clin Neurophysiol 2005; 116: 588-96.

9. Deletis V, Fernandez-Conejero I, Ulkatan S, Costantino P. Methodology for intraoperatively eliciting motor evoked potentials in the vocal muscles by electrical stimulation of the corticobulbar tract. Clin Neurophysiol 2009; 120 : 336-41.

10. Guideline 11A: Recommended Standards for Neurophysiologic Intraoperative Monitoring - Principles, in Society ACN (ed), 2009.

11. Morota N, Ihara S, Deletis V. Intraoperative neurophysiology for surgery in and around the brainstem: role of brainstem mapping and corticobulbar tract motor-evoked potential monitoring. Childs Nerv Syst 2010; 26: 513-21.

12. Simon MV, Michaelides C, Wang S, Chiappa KH, Eskandar EN. The effects of EEG suppression and anesthetics on stimulus thresholds in functional cortical motor mapping. Clin Neurophysiol 2010; 121: 784-92.

13. Polo G, Fischer C, Sindou MP, Marneffe V. Brainstem auditory evoked potentia monitoring during microvascular decompression for hemifacial spasm: intraoperative brainstem auditory evoked potential changes and warning values to prevent hearing loss--prospective study in a consecutive series of 84 patients. Neurosurgery 2004; 54: 97-104.

14. Cochrane DD, Gustavsson B, Poskitt KP, Steinbok P, Kestle JR. The surgical and natural morbidity of aggressive resection for posterior fossa tumors in childhood. Pediatr Neurosurg 1994; 20: 19-29.

15. Dubey A, Sung WS, Shaya M, Patwardhan R, Willis B, Smith D, et al Complications of posterior cranial fossa surgery--an institutional experience of 500 patients. Surg Neurol 2009; 72: 369-75.

16. Fahlbusch R, Strauss C. [Surgical significance of cavernous hemangioma of the brain stem]. Zentralbl Neurochir 1991; 52: 25-32.

17. Deletis V, Fernandez-Conejero I, Ulkatan S, Rogic M, Carbo EL, Hiltzik D. Methodology for intra-operative recording of the corticobulbar motor evoked potentials from cricothyroid muscles. Clin Neurophysiol 2011; 122: 1883-9.

18. Prasad S, Hirsch BE, Kamerer DB, Durrant J, Sekhar LN. Facial nerve function following cerebellopontine angle surgery: prognostic value of intraoperative thresholds. Am J Otol 1993; 14: 330-3.

19. Deletis V, Fernandez-Conejero I. Intraoperative Monitoring and Mapping of the Functional Integrity of the Brainstem. J Clin Neurol 2016; 12: 262-73. 